\title{
Coexistence of Spinal Teratoma of the Conus Medullaris and Arteriovenous Malformation in an Adult: A Case Report
}

\author{
Bir Yetişkinde Konus Medullaris Spinal Teratomu ve Arteriyovenöz \\ Malformasyonun Birlikte Bulunmast: Bir Olgu Sunumu
}

\author{
Jinlu YU, LImei QU, Ye LI, Haiyan HUANG
}

First Hospital of Jilin University, Department of Neurosurgery, Changchun, China

Correspondence address: Haiyan HUANG / E-mail: haiyanhuang@live.cn

\begin{abstract}
The coexistence of spinal teratoma of the conus medullaris and arteriovenous malformation (AVM) is exceptional, which has not been reported previously in the literature. The precise mechanism of the coexistence of these conditions is not known, however, the dysembryonic origin of spinal cord teratoma and AVM seems to play a part in this process. A 34-year-old male patient was admitted with lower back pain, bilateral lower extremity numbness and weakness, and sexual disturbance. Magnetic resonance imaging (MRI) showed an AVM extended cranially from the top of a heterogeneous expansile lesion of the conus medullaris. Surgical exploration and histopathological examination revealed a mature teratoma associated with the AVM. A literature review supported the dysembryonic origin of spinal cord teratomas and AVMs. This unique case may provide insight into the etiopathogenesis of the coexistence of spinal teratoma of the conus medullaris and AVM.
\end{abstract}

KEYWORDS: Spinal teratoma, AVM, Conus medullaris

öz

Konus medullaris spinal teratomu ve arteriyovenöz malformasyonun (AVM) birlikte bulunması çok nadirdir ve literatürde daha önce bildirilmemiştir. Bu iki durumun birlikte bulunmasının tam mekanizması bilinmemektedir ancak spinal kord teratomu ve AVM'nin disembriyonik kökeninin bu süreçte bir rolü var gibidir. 34 yaşında bir erkek hasta bel ağrısı, bilateral alt ekstremite uyuşukluğu ve zayıflı̆ı ve cinsel bozuklukla başvurdu. Manyetik rezonans görüntüleme (MRG) konus medullariste heterojen ekspansil bir lezyonun üzerinden kraniyal olarak uzanan bir AVM gösterdi. Cerrahi eksplorasyon ve histopatolojik inceleme AVM ile ilişkili matür bir teratom gösterdi. Literatür taraması spinal kord teratomları ve AVM'lerin disembriyonik kökenini destekledi. Bu benzersiz vaka konus medullaris spinal teratomu ve AVM'nin birlikte bulunmasının etiyopatogenezi açısından bilgi sağlayabilir.

ANAHTAR SÖZCÜKLER: Spinal teratom, AVM, Konus medullaris

\section{INTRODUCTION}

Spinal teratomas are uncommon neoplasms, with an overall incidence constituting $0.2-0.5 \%$ of all spinal cord lesions (14). The conus medullaris is the most frequent site of an intramedullary teratoma (1). The majority of spinal teratomas coexist with congenital spinal malformations and tumors, such as split-cord malformations or spinal dysraphisms and carcinoid tumors $(5,20)$, but rare cases have been reported to coexist with intraspinal vascular malformations. Here, we present a case of the association of spinal teratoma of the conus medullaris with AVM in an adult. A literature review confirmed that this is the first reported coexistence of these conditions. We also consider the pathogenic and neurosurgical issues involved in such cases.

\section{CASE REPORT}

\section{History and physical examination}

A 34-year-old male patient was admitted with a 2-month history of lower back pain and bilateral lower extremity numbness and weakness. His symptoms were aggravated by exercise, especially walking. In addition, he had experienced sexual disturbance 2 weeks prior to admission. Neurological examination revealed mildly decreased motor function, bilateral grade-IV motor strength in hip flexion, knee extension, dorsiflexion, and plantar flexion, and hypesthesia from the T9-10 to the L1-2 level. Anal wink and sphincter tone were normal. The deep tendon reflexes of the knees and ankle jerks had diminished but were not pathological. No other anomalies, such as hypertrichosis, hemangioma, or dermal sinus tract on the back, were encountered during the physical examination. 


\section{Imaging}

Magnetic resonance imaging (MRI) showed an expansile lesion of the conus medullaris with a heterogeneous appearance indicative of mixed composition at the L1-2 level. Most of the lesion was hyperintense in a $\mathrm{T} 1$ fluid attenuation inversion recovery (FLAIR) sequence, and it exhibited mixed signal intensity in T2-weighted images. No areas of the lesion were enhanced following gadolinium injection. These MRI findings suggested a teratoma.

The MRI additionally revealed intramedullary granular-like high signals in the T1-FLAIR sequence and multiple signal voids on T2-weighted images that suggested an AVM. This malformation extended from the top of the mass of the conus medullaris (L1) to the T12 level on the posterior aspect of the spinal cord. The lesion was enhanced after the administration of contrast. No other spinal malformation was detected by MR or radiographic imaging (Figure 1A-F).

\section{Operation}

The patient underwent a complete L1-2 and partial T12 decompressive lumbar laminectomy and excision of the spinal mass thought to be a teratoma. During surgery, the dura was opened through a midline incision to reveal a yellowish, irregular, fatty, cystic mass at the conus medullaris. The AVM was observed just superior to the mass, connecting

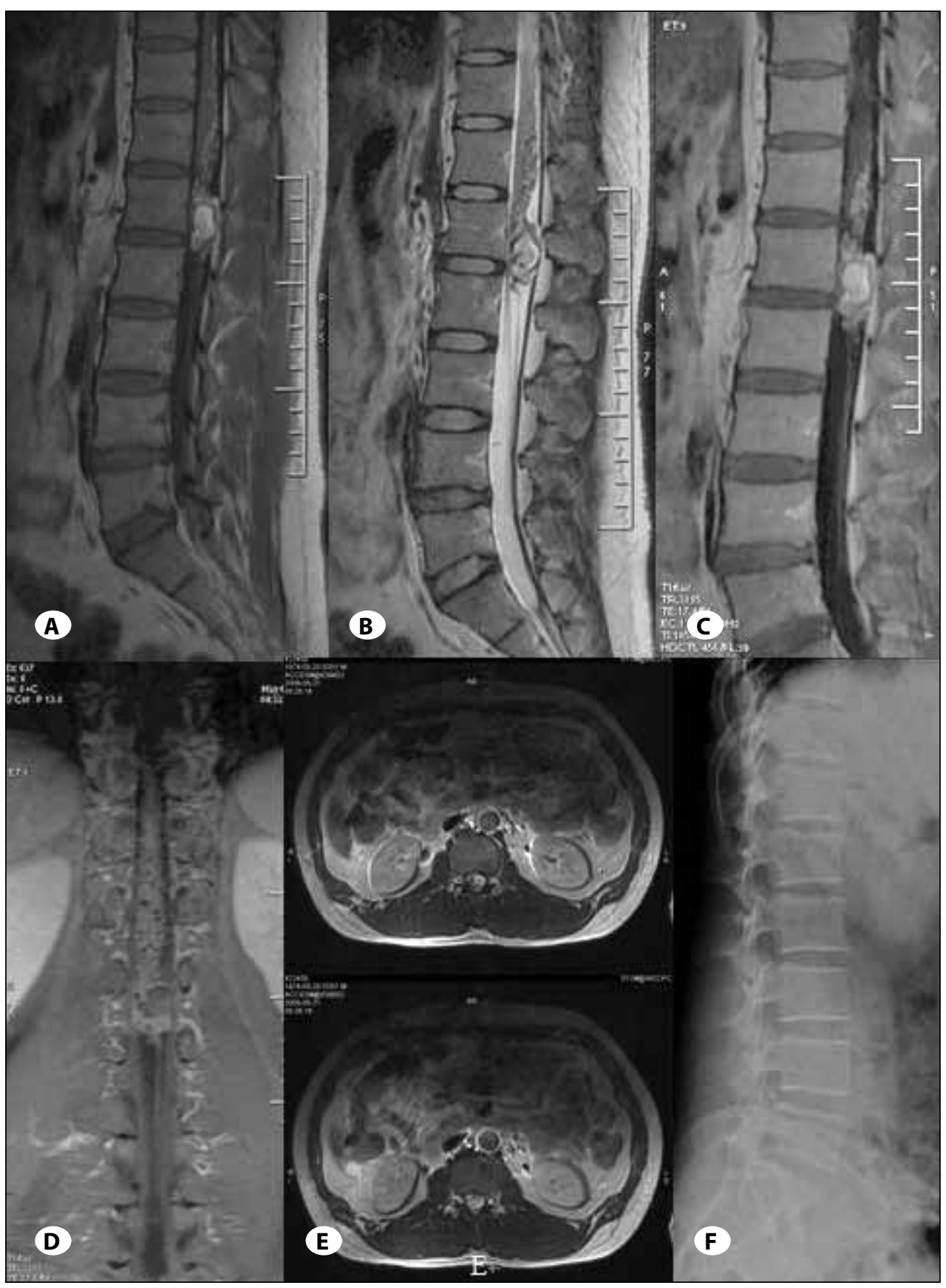

Figure 1: A, B) Preoperative T1-FLAIR and T2-weighted images showing expansile lesion of conus medullaris with heterogeneous appearance, associated with multiple signal voids (AVM) superior to the lesion that connect with the upper pole and extend cranially. C, D) T1-FLAIR images showing unenhanced lesion and enhanced AVM after administration of contrast. E, F) MR and radiographic images showing no other spinal malformations. 

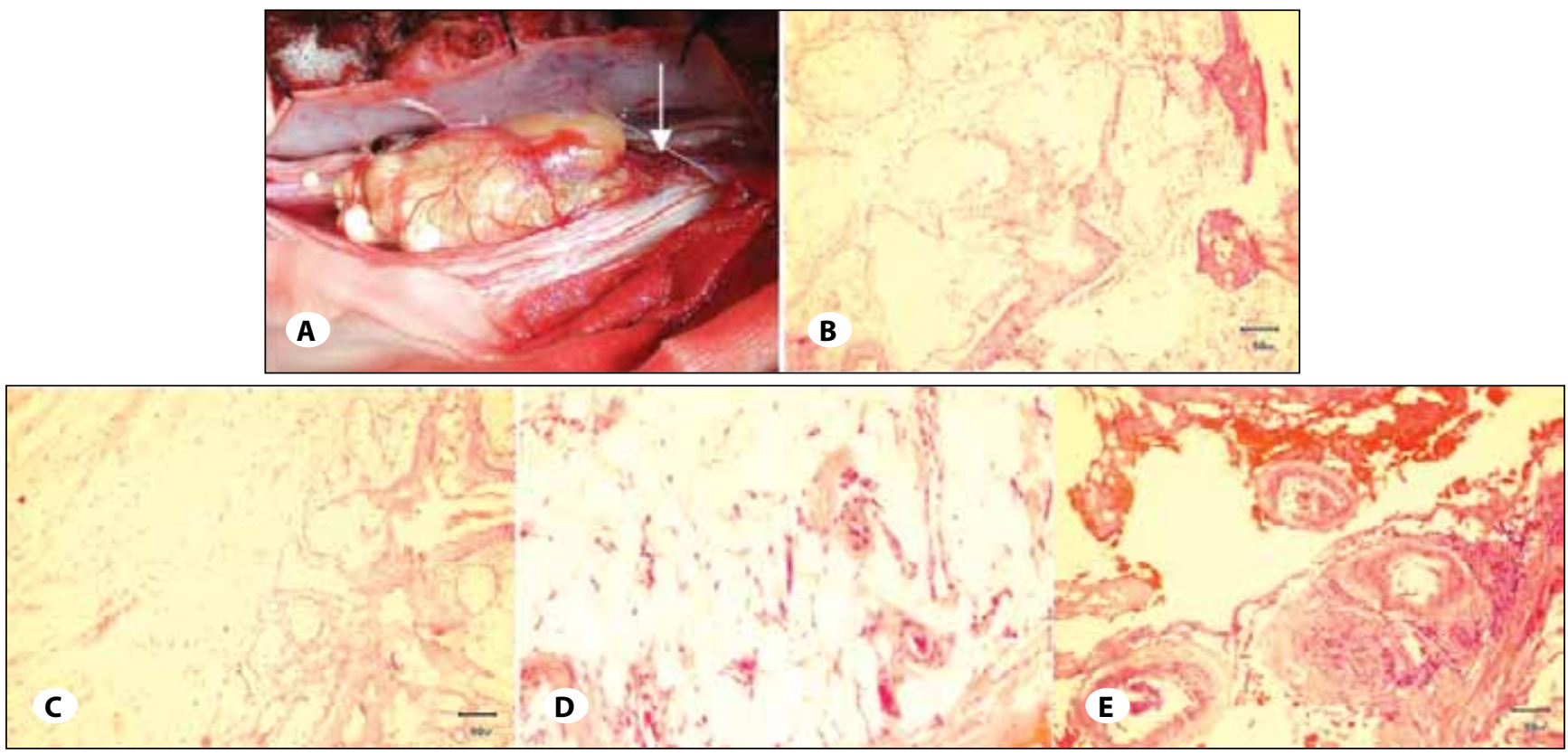

Figure 2: A) Intraoperative photograph after durotomy showing a yellowish fatty cyst and an AVM (arrow) superior to the mass. B, C: Photomicroscopic images showing stratified squamous epithelium with underlying sebaceous glands and other skin adnexal structures $(H \& E$, original magnification $\times 100)$. D) Photomicroscopic images showing mature adipose tissue and vessel cross-section $(\mathrm{H} \& \mathrm{E}$, original magnification $\times 200)$. E) Photomicroscopic images showing an AVM with prominent dilated, thick-walled arteries (H\&E, original magnification $\times 100$ ).

with the upper pole and extending cranially. The adjacent cauda equina was compressed laterally by the cystic mass (Figure 2A). Needle aspiration was first performed to prevent the leakage of cystic fluid into the intradural space. A hairy substance was found in the aspirated fluid. After opening the capsule wall, the entrapped contents were released completely. Because the tumor adhered strongly to the conus medullaris and cauda equina, the spinal cord and the tumor were not separated by a distinct border. Only subtotal tumor resection could be performed under a surgical microscope. Because the upper part of the mass harbored a component of the AVM, they were excised together. No attempt was made to address other components of the AVM. Somatosensory evoked potentials that were used during surgery to avoid further morbidity during the resection of the tumor capsule from the nerve component.

\section{Postoperative course}

The patient experienced no postoperative neurological complications and his strength soon returned to normal. A postoperative $M R I$ revealed that the teratoma had been removed and the AVM was intact (Figure $3 \mathrm{~A}, \mathrm{~B}$ ). The patient continued to experience bilateral lower extremity numbness and lower back pain, but these symptoms resolved completely within 2 months after the surgery. The patient's sexual disturbance did not improve.

\section{Histopathological examination}

Tissues resected from the lesion on the conus medullaris, including the piece harboring the AVM component, were

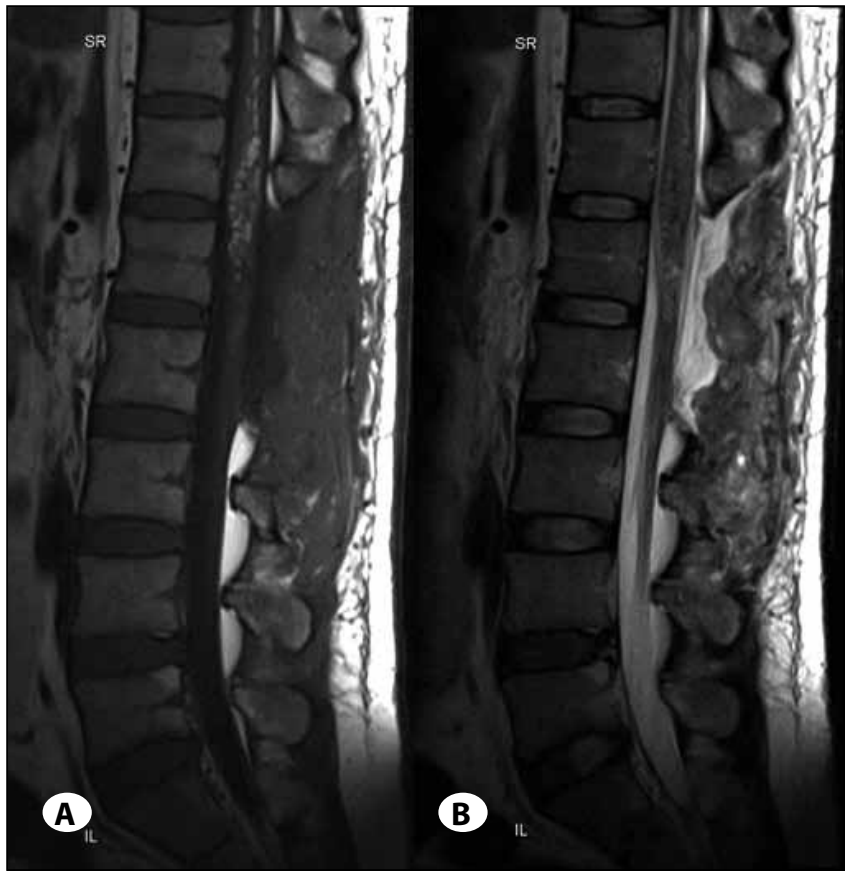

Figure 3A, B: Postoperative T1 and T2-weighted images depicting the tumor was removed and the AVM was intact.

processed in the conventional manner with formalin fixation followed by paraffin embedding. Histopathological analysis indicated that the lesion was composed of mixed tissues from two germ layers, the ectoderm and mesoderm. Microscopic findings showed that the tumor contained stratified squamous 
epithelium with underlying sebaceous glands and other skin adnexal structures. Mature adipose tissue and blood vessels (primarily from the exophytic component) were also found, indicating a mesodermal origin. Microscopic examination showed an AVM in the teratoma, in which dilated thick-walled arteries were prominent. The histopathological diagnosis was a mature cystic teratoma associated with an AVM (Figure 2B-E).

\section{DISCUSSION}

Mature spinal teratomas are uncommon lesions, particularly in adults (6). Most reported patients with spinal teratomas presented with associated spina bifida or other dysplastic spinal abnormalities (14). In a recent study of 27 spinal teratomas, 21 patients had associated features of spinal dysraphism (16). Other lesions have been reported to coexist with teratomas, including lipomas, lipomeningoceles, and carcinoid tumors $(5,22)$. An association with a spinal-cord AVM, however, has not been reported previously in the English-language scientific literature. Spinal-cord AVMs are a relatively rare congenital condition that usually occur alone (4), but they may coexist with other vascular, cutaneous, and skeletal malformations. Some cases of intramedullary AVMs have been reported to coexist with lipomyelomeningoceles $(9,10,19)$.

Teratomas are uncommon intraspinal lesions and their pathogenesis remains unclear (18). A dysembryonic or prenatal origin has recently been proposed, due to the dysfunction of several factors involved in gene functions and cellular inductive interactions (8). Ijiri (6) posited that the misplacement of pluripotential embryonic caudal mesenchymal cells during the secondary neurulation period, preceding closure of the neural tube, resulted in the formation of a teratoma without other spinal malformations. The development of this pluripotent mesenchyma may also expand into other tissues, including blood vessels. The combined lesion may thus be explained by the focal maturation of this pluripotent mesenchyma (primarily as a teratoma) in the primitive vascular plexus, followed by the failure of the capillary component of this plexus to develop (21). Thus, the combination of a spinal-cord teratoma with an AVM most likely originates from mesenchymal tissue that did not regress during the embryonic period.

The preoperative clinical diagnosis of a spinal-cord teratoma is difficult (12). MRI is regarded as the gold-standard technique for the preoperative diagnosis of a teratoma, given the differential intensity of the mass components and the presence of fatty tissue $(13,17)$. In our case, preoperative MRI defined the morphology and localization of the tumor in relation to the conus medullaris, leading us to suspect a teratoma. An AVM was also noted just superior to the tumor, connecting with the upper pole and extending cranially.

Spinal-cord teratomas are treated surgically, and radical removal of the tumor should be the aim of surgical intervention whenever possible $(4,9,10,12,16)$. However, complete surgical resection is difficult in about $50 \%$ of cases because of the intimate adhesion of the tumor to the spinal cord and to the roots of the cauda equina (1,2,11, 14-17). After incomplete removal of the tumor, the remaining endodermal or ectodermal elements may resume growth. Recurrences are most common in immature or malignant teratomas, but growth occurs at a slow rate and the overall survival time for patients with mature teratomas is good (15). The management of spinal-cord AVMs is challenging because treatment-related morbidity is relatively high $(3,7)$. Spontaneous prognosis data are lacking, particularly for asymptomatic $\operatorname{AVMs}(3,23)$.

In our case, only partial resection was possible due to the lack of a distinct border between the spinal cord and the tumor. Because surgical obliteration or excision of intramedullary malformations is difficult at best, and the natural history of asymptomatic unruptured AVMs is unknown (7), only the AVM harbored in the upper teratoma was excised.

Although the coexistence of spinal teratoma of the conus medullaris and AVM is exceptional, neurosurgeons should be aware of their potential association. The present case supports the dysembryonic origin of spinal-cord teratomas and AVMs. Radical resection should be the goal of spinal teratoma treatment, and long-term follow-up is necessary. Long-term observation is the recommended course of action for an associated asymptomatic and unruptured AVM.

\section{REFERENCES}

1. Ak H, Ulu MO, Sar M, Albayram S, Aydin S, Uzan M: Adult intramedullary mature teratoma of the spinal cord: Review of the literature illustrated with an unusual example. Acta Neurochir (Wien) 148:663-669, 2006

2. Allsopp G, Sgouros S, Barber P, Walsh AR: Spinal teratoma: Is there a place for adjuvant treatment? Two cases and a review of the literature. Br J Neurosurg 14:482-488, 2000

3. Boström A, Krings T, Hans FJ, Schramm J, Thron AK, Gilsbach JM: Spinal glomus-type arteriovenous malformations: Microsurgical treatment in 20 cases. J Neurosurg Spine 10:423-429, 2009

4. Corkill RA, Mitsos AP, Molyneux AJ: Embolization of spinal intramedullary arteriovenous malformations using the liquid embolic agent, Onyx: A single-center experience in a series of 17 patients. J Neurosurg Spine 7:478-485, 2007

5. Fan X, Turner JE, Turner TM, Elrod JP, Clough JA, Howell $\mathrm{El}$, Johnson MD: Carcinoid tumor development in an intramedullary spinal cord mature teratoma. Am J Neuroradiol 22:1778-1781, 2001

6. Ijiri K, Hida K, Yano S, Iwasaki Y: Huge intradural ossification caused by a mature spinal teratoma:case report. Neurosurgery 64:E1200-1201, 2009

7. Kenning TJ, Deshaies EM, Adamo MA, Waldman JB, Boulos AS: Onyx embolization of a thoracolumbar perimedullary spinal arteriovenous fistula in an infant presenting with subarachnoid and intraventricular hemorrhage. J Neurosurg Pediatr 3:211-214, 2009 
8. Koen JL, McLendon RE, George TM: Intradural spinal teratoma: Evidence for a dysembryogenic origin. Report of four cases. J Neurosurg 89:844-851, 1998

9. König M, Hentsch A, Schmieder K, Harders A, Heuser L: Extraspinal dural arteriovenous fistula in a patient with lipomyelodysplasia: Value of MRI and MRA. Neuroradiology 41:579-583, 1999

10. Lee JH, Chung CK, Choe G, Chi JG, Chang KH, Kim HJ:Combined anomaly of intramedullary arteriovenous malformation and lipomyelomeningocele. Am J Neuroradiol 21:595-600, 2000

11. Makary R, Wolfson D, Dasilva V, Mohammadi A, Shuja S: Intramedullary mature teratoma of the cervical spinal cord at C1-2 associated with occult spinal dysraphism in an adult. Case report and review of the literature. J Neurosurg Spine 6:579-584, 2007

12. Mut M, Shaffrey ME, Bourne TD, Jagannathan J, Shaffrey $\mathrm{Cl}$ : Unusual presentation of an adult intramedullary spinal teratoma with diplomyelia. Surg Neurol 67: 190-194, 2007

13. Nicoletti GF, Passanisi M, Platania N, Lanzafame S, Albanese V: Intramedullary spinal cystic teratoma of the conus medullaris with caudal exophytic development: Case report. Surg Neurol 41:106-111, 1994

14. Nonomura $Y$, Miyamoto $K$, Wada E, Hosoe $H$, Nishimoto $H$, Ogura $\mathrm{H}$, Shimizu K: Intramedullary teratoma of the spine: Report of two adult cases. Spinal Cord 40:40-43, 2002

15. Poeze M, Herpers MJ, Tjandra B, Freling G, Beuls EA: Intramedullary spinal teratoma presenting with urinary retention: Case report and review of the literature. Neurosurgery 45:379-385, 1999
16. Sharma MC, Jain D, Sarkar C, Suri V, Garg A, Singh M, Mahapatra AK, Sharma BS: Spinal teratomas: A clinico-pathological study of 27 patients. Acta Neurochir (Wien) 151:245-252, 2009

17. Sung KS, Sung SK, Choi HJ, Song YJ: Spinal intradural extramedullary mature cystic teratoma in an adult. J Korean Neurosurg Soc 44:334-337, 2008

18. Tsitsopoulos P, Rizos C, Isaakidis D, Liapi G, Zymaris S: Coexistence of spinal intramedullary teratoma and diastematomyelia in an adult. Spinal Cord 44:632-635, 2006

19. Tubbs RS, Oakes WJ: Lipomyelomeningocele and arteriovenous malformation: Case reports and a review of the literature. Childs Nerv Syst 22:628-631, 2006

20. Uzüm N, Dursun A, Baykaner K, Kurt G: Split-cord malformation and tethered cord associated with immature teratoma. Childs Nerv Syst 21:77-80, 2005

21. Walsh JW, Markesbery WR: Histological features of congenital lipomas of the lower spinal canal. J Neurosurg 52:564-569, 1980

22. Weon YC, Chung Jl, Roh HG, Eoh W, Byun HS: Combined spinal intramedullary arteriovenous malformation and lipomyelomeningocele. Neuroradiology 47:774-779, 2005

23. Zozulya YP, Slin'ko El, Al-Qashqish II: Spinal arteriovenous malformations: New classification and surgical treatment. Neurosurg Focus 20:E7, 2006 